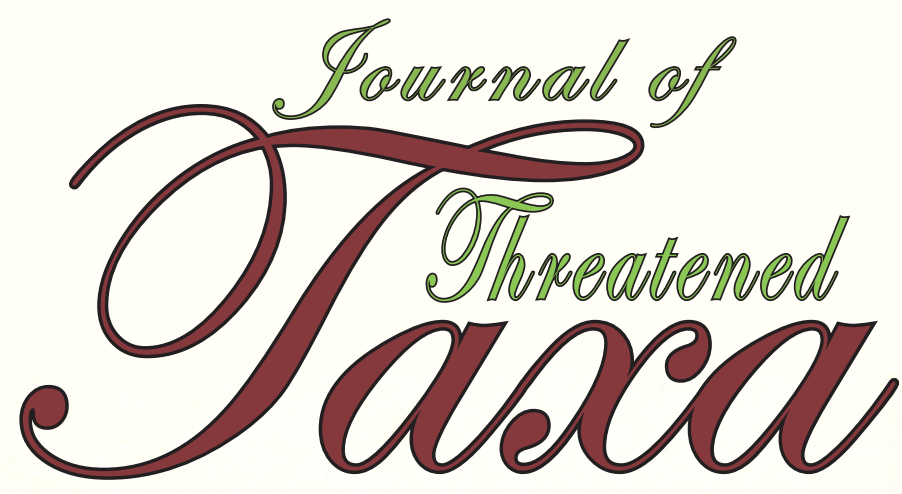

10.11609/jott.2021.13.14.20143-20310 enever.threatenedtaxa.org

26 December 2021 (Online \& Print) Val. 13 | Na. 14 | Pages: 20143-20310 155n 0974-7907 (Online) 155n 0974-7893 (Print)

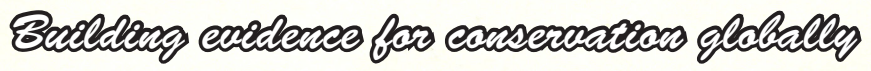

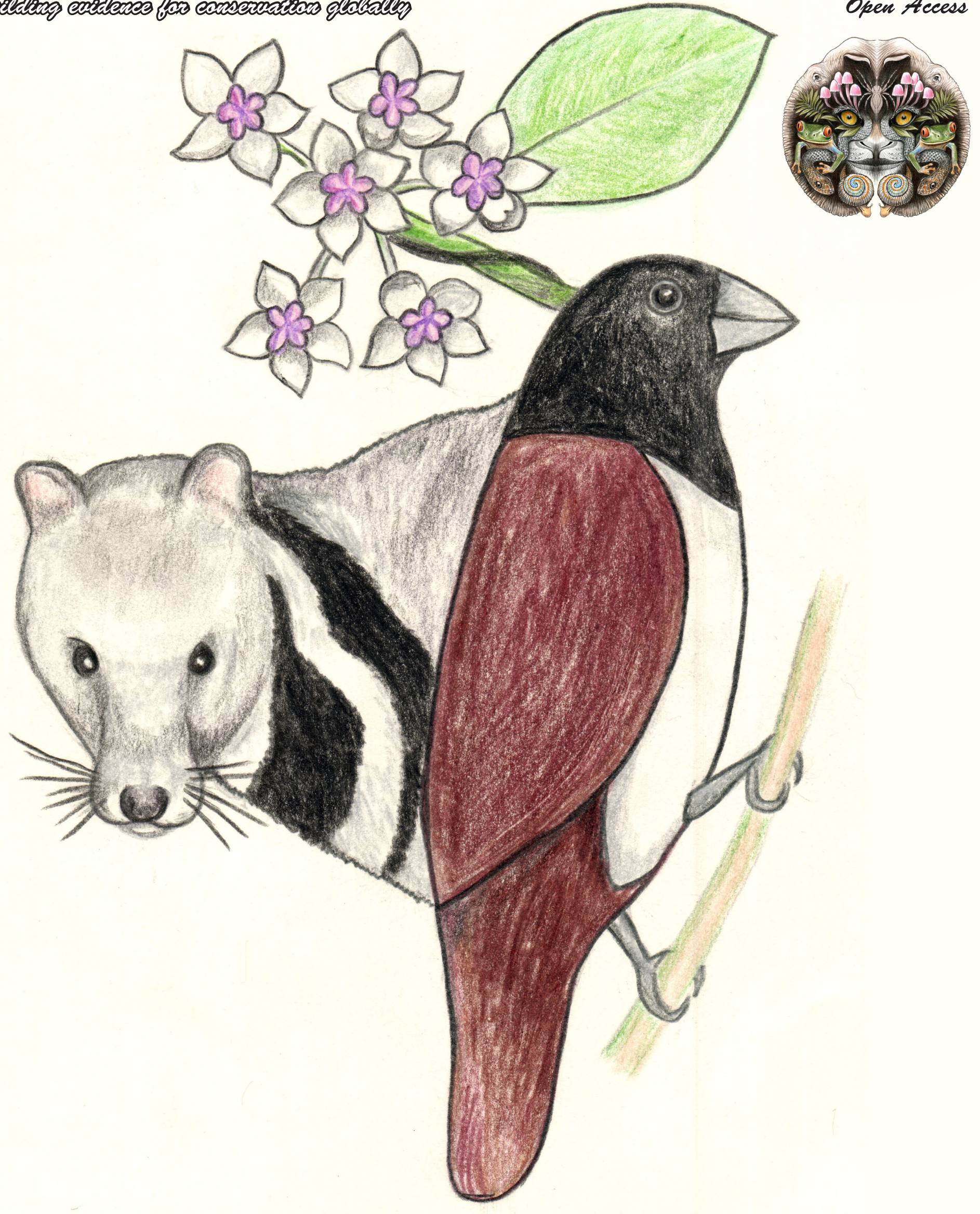

Open Access 


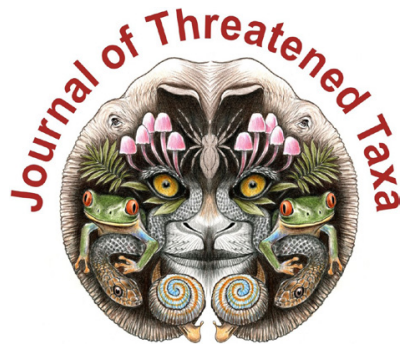

ISSN 0974-7907 (Online); ISSN $0974-7893$ (Print)

Publisher

Host

Wildlife Information Liaison Development Society

www.wild.zooreach.org

Zoo Outreach Organization www.zooreach.org

No. 12, Thiruvannamalai Nagar, Saravanampatti - Kalapatti Road, Saravanampatti, Coimbatore, Tamil Nadu 641035, India

Ph: +91 9385339863 | www.threatenedtaxa.org

Email: sanjay@threatenedtaxa.org

EDITORS

\section{Founder \& Chief Editor}

Dr. Sanjay Molur

Wildlife Information Liaison Development (WILD) Society \& Zoo Outreach Organization (ZOO),

12 Thiruvannamalai Nagar, Saravanampatti, Coimbatore, Tamil Nadu 641035, India

\section{Deputy Chief Editor}

Dr. Neelesh Dahanukar

Noida, Uttar Pradesh, India

\section{Managing Editor}

Mr. B. Ravichandran, WILD/ZOO, Coimbatore, India

\section{Associate Editors}

Dr. Mandar Paingankar, Government Science College Gadchiroli, Maharashtra 442605, India

Dr. Ulrike Streicher, Wildlife Veterinarian, Eugene, Oregon, USA

Ms. Priyanka lyer, ZOO/WILD, Coimbatore, Tamil Nadu 641035, India

Dr. BA. Daniel, $200 / \mathrm{WILD}$, Coimbatore, Tamil Nadu 641035, India

\section{Editorial Board}

Dr. Russel Mittermeie

Executive Vice Chair, Conservation International, Arlington, Virginia 22202, USA

\section{Prof. Mewa Singh Ph.D., FASc, FNA, FNASc, FNAPsy}

Ramanna Fellow and Life-Long Distinguished Professor, Biopsychology Laboratory, and Institute of Excellence, University of Mysore, Mysuru, Karnataka 570006, India; Honorary Professor, Jawaharlal Nehru Centre for Advanced Scientific Research, Bangalore; and Adjunct Professor, National Institute of Advanced Studies, Bangalore

\section{Stephen D. Nash}

Scientific Illustrator, Conservation International, Dept. of Anatomical Sciences, Health Sciences Center, T-8, Room 045, Stony Brook University, Stony Brook, NY 11794-8081, USA

\section{Dr. Fred Pluthero}

Toronto, Canada

\section{Dr. Priya Davidar}

Sigur Nature Trust, Chadapatti, Mavinhalla PO, Nilgiris, Tamil Nadu 643223, India

\section{Dr. Martin Fisher}

Senior Associate Professor, Battcock Centre for Experimental Astrophysics, Cavendish

Laboratory, JJ Thomson Avenue, Cambridge CB3 OHE, UK

\section{Dr. John Fellowes}

Honorary Assistant Professor, The Kadoorie Institute, 8/F, T.T. Tsui Building, The University of Hong Kong, Pokfulam Road, Hong Kong

\section{Prof. Dr. Mirco Solé}

Universidade Estadual de Santa Cruz, Departamento de Ciências Biológicas, Vice-coordenado do Programa de Pós-Graduação em Zoologia, Rodovia Ilhéus/Itabuna, Km 16 (45662-000)

Salobrinho, Ilhéus - Bahia - Brasil

\section{Dr. Rajeev Raghavan}

Professor of Taxonomy, Kerala University of Fisheries \& Ocean Studies, Kochi, Kerala, India

\section{English Editors}

Mrs. Mira Bhojwani, Pune, India

Dr. Fred Pluthero, Toronto, Canad

Mr. P. Ilangovan, Chennai, India

Web Development

Mrs. Latha G. Ravikumar, ZOO/WILD, Coimbatore, India

\section{Typesetting}

Mr. Arul Jagadish, ZOO, Coimbatore, India

Mrs. Radhika, ZOO, Coimbatore, India

Mrs. Geetha, ZOO, Coimbatore India
Fundraising/Communications

Mrs. Payal B. Molur, Coimbatore, India

Subject Editors 2018-2020

Fungi

Dr. B. Shivaraju, Bengaluru, Karnataka, India

Dr. R.K. Verma, Tropical Forest Research Institute, Jabalpur, India

Dr. Vatsavaya S. Raju, Kakatiay University, Warangal, Andhra Pradesh, India

Dr. M. Krishnappa, Jnana Sahyadri, Kuvempu University, Shimoga, Karnataka, India

Dr. K.R. Sridhar, Mangalore University, Mangalagangotri, Mangalore, Karnataka, India

Dr. Gunjan Biswas, Vidyasagar University, Midnapore, West Bengal, India

\section{Plants}

Dr. G.P. Sinha, Botanical Survey of India, Allahabad, India

Dr. N.P. Balakrishnan, Ret. Joint Director, BSI, Coimbatore, India

Dr. Shonil Bhagwat, Open University and University of Oxford, UK

Prof. D.J. Bhat, Retd. Professor, Goa University, Goa, India

Dr. Ferdinando Boero, Università del Salento, Lecce, Italy

Dr. Dale R. Calder, Royal Ontaro Museum, Toronto, Ontario, Canada

Dr. Cleofas Cervancia, Univ. of Philippines Los Baños College Laguna, Philippines

Dr. F.B. Vincent Florens, University of Mauritius, Mauritius

Dr. Merlin Franco, Curtin University, Malaysia

Dr. V. Irudayaraj, St. Xavier's College, Palayamkottai, Tamil Nadu, India

Dr. B.S. Kholia, Botanical Survey of India, Gangtok, Sikkim, India

Dr. Pankaj Kumar, Kadoorie Farm and Botanic Garden Corporation, Hong Kong S.A.R., China

Dr. V. Sampath Kumar, Botanical Survey of India, Howrah, West Bengal, India

Dr. A.J. Solomon Raju, Andhra University, Visakhapatnam, India

Dr. Vijayasankar Raman, University of Mississippi, USA

Dr. B. Ravi Prasad Rao, Sri Krishnadevaraya University, Anantpur, India

Dr. K. Ravikumar, FRLHT, Bengaluru, Karnataka, India

Dr. Aparna Watve, Pune, Maharashtra, India

Dr. Qiang Liu, Xishuangbanna Tropical Botanical Garden, Yunnan, China

Dr. Noor Azhar Mohamed Shazili, Universiti Malaysia Terengganu, Kuala Terengganu, Malaysia

Dr. M.K. Vasudeva Rao, Shiv Ranjani Housing Society, Pune, Maharashtra, India

Prof. A.J. Solomon Raju, Andhra University, Visakhapatnam, India

Dr. Mandar Datar, Agharkar Research Institute, Pune, Maharashtra, India

Dr. M.K. Janarthanam, Goa University, Goa, India

Dr. K. Karthigeyan, Botanical Survey of India, India

Dr. Errol Vela, University of Montpellier, Montpellier, France

Dr. P. Lakshminarasimhan, Botanical Survey of India, Howrah, India

Dr. Larry R. Noblick, Montgomery Botanical Center, Miami, USA

Dr. K. Haridasan, Pallavur, Palakkad District, Kerala, India

Dr. Analinda Manila-Fajard, University of the Philippines Los Banos, Laguna, Philippines

Dr. P.A. Sinu, Central University of Kerala, Kasaragod, Kerala, India

Dr. Afroz Alam, Banasthali Vidyapith (accredited A grade by NAAC), Rajasthan, India

Dr. K.P. Rajesh, Zamorin's Guruvayurappan College, GA College PO, Kozhikode, Kerala, India

Dr. David E. Boufford, Harvard University Herbaria, Cambridge, MA 02138-2020, USA

Dr. Ritesh Kumar Choudhary, Agharkar Research Institute, Pune, Maharashtra, India

Dr. Navendu Page, Wildlife Institute of India, Chandrabani, Dehradun, Uttarakhand, India

\section{Invertebrates}

Dr. R.K. Avasthi, Rohtak University, Haryana, India

Dr. D.B. Bastawade, Maharashtra, India

Dr. Partha Pratim Bhattacharjee, Tripura University, Suryamaninagar, India

Dr. Kailash Chandra, Zoological Survey of India, Jabalpur, Madhya Pradesh, India

Dr. Ansie Dippenaar-Schoeman, University of Pretoria, Queenswood, South Africa

Dr. Rory Dow, National Museum of natural History Naturalis, The Netherlands

Dr. Brian Fisher, California Academy of Sciences, USA

Dr. Richard Gallon, llandudno, North Wales, LL30 1UP

Dr. Hemant V. Ghate, Modern College, Pune, India

Dr. M. Monwar Hossain, Jahangirnagar University, Dhaka, Bangladesh

Mr. Jatishwor Singh Irungbam, Biology Centre CAS, Branišovská, Czech Republic.

Dr. Ian J. Kitching, Natural History Museum, Cromwell Road, UK

Dr. George Mathew, Kerala Forest Research Institute, Peechi, India

For Focus, Scope, Aims, and Policies, visit https://threatenedtaxa.org/index.php/JoTT/aims_scope
For Article Submission Guidelines, visit https://threatenedtaxa.org/index.php/JoTT/about/submissions
For Policies against Scientific Misconduct, visit https://threatenedtaxa.org/index.php/JoTT/policies_various 


\title{
Diversity and distribution of macro lichens from Kalpetta Municipality of Wayanad District, Kerala, India
}

\author{
Greeshma Balu ${ }^{1}$ (D), A.R. Rasmi ${ }^{2}$ (D), Stephen Sequeira ${ }^{3}$ (D) \& Biju Haridas ${ }^{4}$ (D) \\ 1,2 Post Graduate and Research Department of Botany, Govt. Victoria College, Palakkad, Kerala 678001, India. \\ ${ }^{3}$ Lichenology Lab, Post Graduate and Research Department of Botany,, Maharajas College, Ernakulum, Kerala 682011, India. \\ ${ }^{4}$ Microbiology Division, Jawaharlal Nehru Tropical Botanical garden and Research Institute, Palode, Thiruvananthapuram, \\ Kerala 695562, India. \\ ${ }^{1}$ kichugreeshma2@gmail.com, ${ }^{2}$ rasmibotany@gmail.com (corresponding author), ${ }^{3}$ step@rediffmail.com, ${ }^{4}$ drbijutbgri@gmail.com
}

Abstract: Macro lichens of Kalpetta Municipality of Wayanad District of Kerala state were studied. The study revealed about 21 macro lichen species. All the species identified are either foliose or fruticose forms belonging to families Coccocarpiaceae, Caliciaceae, Physciaceae, Parmeliaceae, Collemataceae, Lobariaceae, and Ramalinaceae indicating the dominance of these groups in the study area.

Keywords: Caliciaceae, Coccocarpiaceae, Collemataceae, foliose fruticose, lichen diversity, Lobariaceae, Parmeliaceae, Physciaceae, Ramalinaceae.

India has a rich lichen diversity, represented by 2,513 species, 64 varieties and eight subspecies distributed in various regions (Nayaka 2014). Sinha et al. (2018) added publications after 2010 and recorded 2,714 species, about $14 \%$ of the total global lichen flora. Kerala has a rich lichen diversity, especially of micro forms, and exploration of the Western Ghats (Patwardhan 1983) have identified $>400$ species. Singh \& Sinha (2010) listed 75 references related to lichen studies in Kerala, including reports by Kumar (2000), Easa (2003), Sequiera (2003 \& 2007), Singh \& Sinha (2010), and Biju et al. (2010).
Later reports include Nayaka \& Upreti (2011), Biju et al. (2012), Bhat et al. (2011), Mesta \& Kanivebagilu (2015), Sreekumar et al. (2017), and Zachariah et al. (2018, 2019, 2020). Nevertheless, several interesting habitats such as croplands, wetlands, and coastal areas remain unexplored.

Wayanad is a botanically rich area in Kerala, with an altitude ranging from 700 to $2,100 \mathrm{~m}$. About $886 \mathrm{~km}^{2}$ of the district is under forest. Kumar \& Sequiera (2003) studied lichens from Chembra and Thirunelly hills of Wayanad District, but many gaps remain regarding this region. This study presents the first description of the diversity and distribution of macro lichens of Kalpetta municipality area of Wayanad district, which includes both natural forests and cultivated land.

\section{Materials AND Methods \\ Study area}

Wayanad is situated at $11.685^{\circ} \mathrm{N}, 76.132^{\circ} \mathrm{E}$ (Figure 1). The Wayanad plateau is one of the hotspot regions in the Western Ghats, and is part of the Nilgiri

Citation: Balu,, G., A.R. Rasmi, S. Sequeira \& B. Haridas (2021). Diversity and distribution of macro lichens from Kalpetta Municipality of Wayanad District, Kerala, India. Journal of Threatened Taxa 13(14): 20253-20257. https://doi.org/10.11609/jott.6706.13.14.20253-20257

Copyright: (C) Balu et al. 2021. Creative Commons Attribution 4.0 International License. JoTT allows unrestricted use, reproduction, and distribution of this article in any medium by providing adequate credit to the author(s) and the source of publication.

Funding: This work was funded by the Student project scheme of Kerala State Council for Science, Technology and Environment (File No: 01196/SPS 64/2019/KSCSTE)

Competing interests: The authors declare no competing interests.
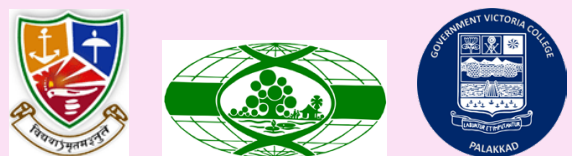

Acknowledgements: The authors are thankful to principals and heads of the Department of Botany, Maharaja's College, Ernakulam and Government Victoria College, Palakkad for providing necessary facilities. Thanks are also due to Arun Christy Sebastian, Aswathi Anilkumar, and Arsha S Mohan, research scholars, Lichenology Laboratory, Department of Botany, Maharaja's College, Ernakulam for the help rendered during the study. The first and third authors acknowledges Kerala State Council for Science, Technology and Environment (KSCSTE), Govt. of Kerala for the financial support. A special thanks to Aswin Sai who accompanied throughout the collection. 


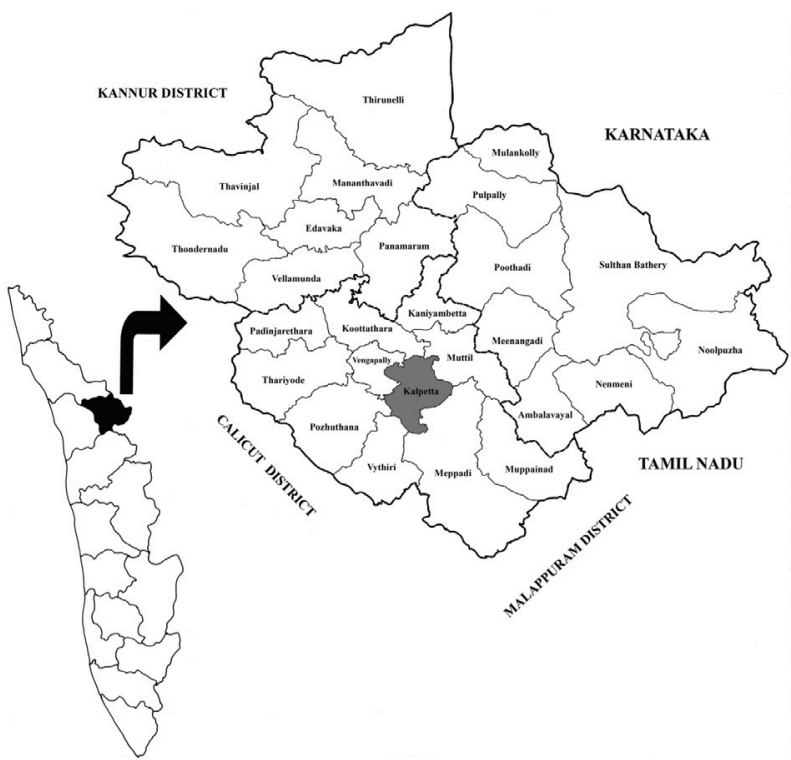

Figure 1. Location map of Wayanad district.

Biosphere Reserve. There are three municipal towns: Kalpetta, Mananthavady, and Sulthan Bathery. Kalpetta municipality comes under Vythiri Taluk and consists of 28 wards (Figure 2). The area is surrounded by coffee and tea plantations, and mountain ranges.

\section{Lichen samples}

A total of 112 lichen specimens were collected from 28 wards of Kalpetta Municipality during several field visits (Table 1). Samples were collected in brown acidfree bags of appropriate sizes. Corticolous and saxicolous lichens were collected along with the substratum using sharp chisels. Much care was taken to collect these specimens without any damage to the thallus margins. Fruticose lichens were collected with their holdfasts intact. All specimens were serially numbered in the field according to the date of collection. Characters of lichens which might be lost during drying and preservationsuch as the colour of the thallus, reproductive structures, orientation of the specimen, details of associated plants, collection date, locality, and nature of substratumwere noted.

The specimens were dried, and the morphological details were examined under stereo zoom Leica S8 microscope, while anatomical details were examined with a Leica DM 1000 compound microscope with camera and image analysis software. Chemistry was studied by spot tests using $10 \%$ aqueous solution of potassium hydroxide, freshly prepared aqueous solution of calcium hypochlorite, $1-5 \%$ solution of para phenylenediamine and iodine solution. Thin layer

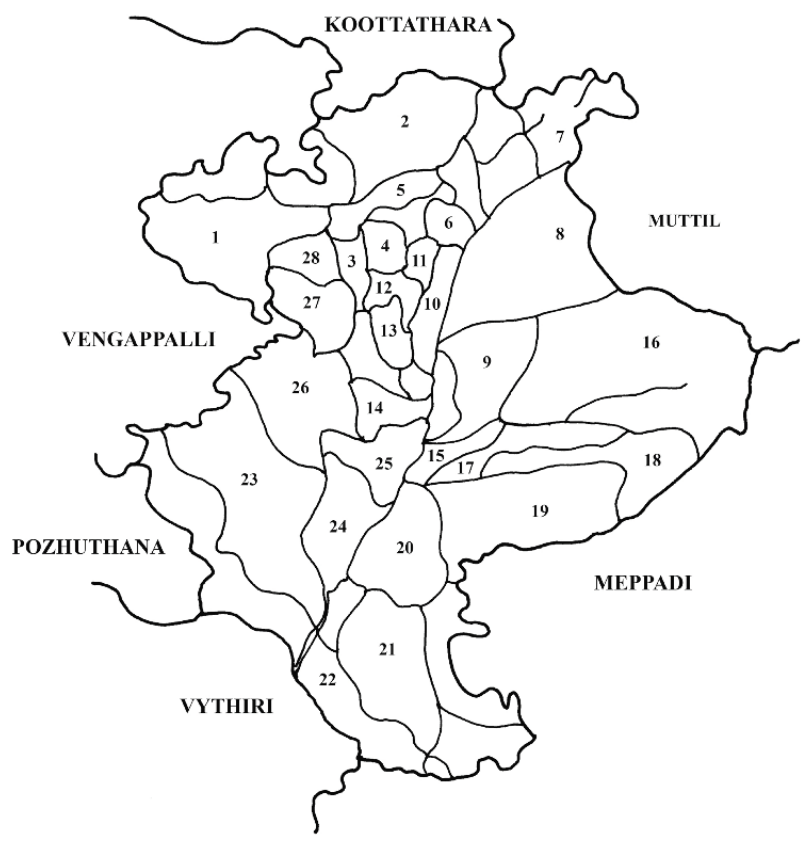

Figure 2. Map of Kalpetta Municipality showing collection localities. 1-Maniangode | 2-Puliyarmal | 3-Govt. High School | 4Nedungode | 5-Emily | 6-Kanyagurukulam | 7-Kainatty | 8Civil station | 9-Chathothuvayal 10-Municipal Office | 11-Emily Thadam | 12-Ambilery | 13-Gramathu vayal | 14-Pallythazhe | 15-Puthiya Bus stand | 16-Pulpara | 17-Rattakolly | 18Puthoorvayal Quarry | 19-Puthoorvayal | 20-Madiyoorkuni | 21Perumthatta | 22-Vellaramkunnu | 23-Adlayed | 24-Onivayal | 25-Turkey | 26-Edaguni | 27-Munderi | 28-Maravayal.

chromatography was performed in solvent system C following Orange et al. (2001). Recent literature, keys and descriptions (Awasthi 1991, 2007; Divakar \& Upreti 2005; Wijayawardene et al. 2020) were followed for identification. Nomenclature was confirmed with the database Index Fungorum (http://www.IndexFungorum. org). Lichens were grouped on the basis of collected localities, type of growth forms, type of fungal partner etc. The identified specimens were deposited at the Lichen Herbarium, Department of Botany, Maharaja's College (Autonomous), Ernakulam, Kerala.

\section{RESULTS AND DISCUSSION}

Analysis of the collected specimens revealed 21 species belonging to seven families from the study area (Table 2). Of the identified samples, 20 were foliose and the remaining one, Ramalina sp. was fruticose. The family Physciaceae dominated with 10 species under three genera, followed by Parmeliaceae (5 species under 3 genera), Collemataceae (2 species under 1 genus), Coccocarpiaceae, Caliciaceae, Lobariaceae, and Ramalinaceae with one species and one genus. The genus Heterodermia dominated with seven species 
Table 1. Details of localities surveyed.

\begin{tabular}{|l|c|c|c|}
\hline Name of wards & Latitude & Longitude & Altitude \\
\hline Munderi & $11.620521^{\circ} \mathrm{N}$ & $76.070955^{\circ} \mathrm{E}$ & $728.33 \mathrm{~m}$ \\
\hline Emily & $11.626677^{\circ} \mathrm{N}$ & $76.080325^{\circ} \mathrm{E}$ & $760.99 \mathrm{~m}$ \\
\hline Turkey & $11.606147^{\circ} \mathrm{N}$ & $76.078668^{\circ} \mathrm{E}$ & $733.91 \mathrm{~m}$ \\
\hline Ambilery & $11.621339^{\circ} \mathrm{N}$ & $76.07773^{\circ} \mathrm{E}$ & $669.18 \mathrm{~m}$ \\
\hline Vellaramkunnu & $11.586156^{\circ} \mathrm{N}$ & $76.06881^{\circ} \mathrm{E}$ & $840.67 \mathrm{~m}$ \\
\hline Onivayal & $11.586156^{\circ} \mathrm{N}$ & $76.06881^{\circ} \mathrm{E}$ & $840.67 \mathrm{~m}$ \\
\hline Gramathuvayal & $11.618029^{\circ} \mathrm{N}$ & $76.078388^{\circ} \mathrm{E}$ & $712.88 \mathrm{~m}$ \\
\hline Maravayal & $11.620512^{\circ} \mathrm{N}$ & $76.071083^{\circ} \mathrm{E}$ & $723.79 \mathrm{~m}$ \\
\hline Adlayed & $11.594902^{\circ} \mathrm{N}$ & $76.06158^{\circ} \mathrm{E}$ & $768.18 \mathrm{~m}$ \\
\hline Pallythazhe & $11.614368^{\circ} \mathrm{N}$ & $76.080902^{\circ} \mathrm{E}$ & $721.18 \mathrm{~m}$ \\
\hline Maniangode & $11.631595^{\circ} \mathrm{N}$ & $76.065617^{\circ} \mathrm{E}$ & $729.76 \mathrm{~m}$ \\
\hline Puthiya Bus Stand & $11.607427^{\circ} \mathrm{N}$ & $76.085316^{\circ} \mathrm{E}$ & $766.97 \mathrm{~m}$ \\
\hline Municipal Office & $11.621060^{\circ} \mathrm{N}$ & $76.08349^{\circ} \mathrm{E}$ & $767.97 \mathrm{~m}$ \\
\hline Rattakolly & $11.602431^{\circ} \mathrm{N}$ & $76.08917^{\circ} \mathrm{E}$ & $764.76 \mathrm{~m}$ \\
\hline Chathothuvayal & $11.618887^{\circ} \mathrm{N}$ & $76.086036^{\circ} \mathrm{E}$ & $754.28 \mathrm{~m}$ \\
\hline Nedungode & $11.625475^{\circ} \mathrm{N}$ & $76.080638^{\circ} \mathrm{E}$ & $776.5 \mathrm{~m}$ \\
\hline Govt.High School & $11.624791^{\circ} \mathrm{N}$ & $76.072009^{\circ} \mathrm{E}$ & $725.85 \mathrm{~m}$ \\
\hline Kainatty & $11.636633^{\circ} \mathrm{N}$ & $76.088925^{\circ} \mathrm{E}$ & $741.82 \mathrm{~m}$ \\
\hline Ambilery & $11.625269^{\circ} \mathrm{N}$ & $76.012530^{\circ} \mathrm{E}$ & $670.18 \mathrm{~m}$ \\
\hline Puliyarmala & $11.638559^{\circ} \mathrm{N}$ & $76.081451^{\circ} \mathrm{E}$ & $669.04 \mathrm{~m}$ \\
\hline Pulpara & $11.605586^{\circ} \mathrm{N}$ & $76.089836^{\circ} \mathrm{E}$ & $774.33 \mathrm{~m}$ \\
\hline Kanyagurukulam & $76.0834959^{\circ} \mathrm{N}{ }^{\circ} \mathrm{N}$ & $76.092082^{\circ} \mathrm{E} \mathrm{N}$ & $746.43 \mathrm{~m}$ \\
\hline Puthoorvayal & $76.081403^{\circ} \mathrm{E}$ & $602.6 \mathrm{~m}$ \\
\hline Puthoorvayal Quarry & $76.079384^{\circ} \mathrm{E}$ & $743.73 \mathrm{~m}$ \\
\hline Emily Thadam & $7678613^{\circ} \mathrm{E}$ & $714.88 \mathrm{~m}$ \\
\hline Gramathuvayal & $76.094251^{\circ} \mathrm{E}$ & $779.86 \mathrm{~m}$ \\
\hline Madiyoorkuni & $11.69636^{\circ} \mathrm{E}$ & $779.69 \mathrm{~m}$ \\
\hline Edaguni & $11.68 \mathrm{~N}$ & \\
\hline
\end{tabular}

followed by Parmotrema (3 species), Physcia ( 2 species), and Leptogium (2 species). Kumar (2000), recorded about 254 macrolichens from Kerala part of Western Ghats among which he recorded 18 species from Thirunelly and 14 species from Pakshipadalam area of Wayanad.

Corticolous species were dominated in both the natural as well as the cultivated ecosystems. Species such as Leptogium denticulatum, Myelochroa perisidians, and Phaeophyscia ciliata were found to be saxicolous in nature, while all others were corticolous inhabiting either on the trunks or branches of arboreal elements in the study area. Trunks of trees and small or medium sized rocks inside the ecosystems are the main microhabitats for most of the macrolichens in the study area. Environmental factors influence the lichen community to a great extent and these organisms are very much sensitive to environmental changes and microhabitat has significant influence on lichen distribution (Fryday 2000).

Trees near road side like Bauhinia purpurea, Mangifera indica, Bixa orellana, Roystonea regia, Casuarina equisetifolia, and Cassia fistula hold very few lichen species such as Coccocarpia palmicola, Phaeophyscia ciliatea, and Pseudocyphellaria aurata. However, trees which are closer to the natural forests like Artocarpus hirsutus, Dalbergia latifolia, Phyllanthus emblica, Helicteres isora, Ficus sp., Mimusops elengi, Alstonia scholaris, and Lagerstroemia microcarpa exhibit more lichens on their trunks and branches. Species like Heterodermia comosa, $H$. galactophylla, $H$. hypochraea, H. speciosa, Leptogium denticulatum, and Myelochroa perisidians were found distributed here. Environmental factors such as, light, humidiy, rainfall, and stable microclimatic factors govern the distribution of lichen species in such habitats. The result shows strong competitive capability of some lichens and its wide ecological amplitude to survive on the road side trees which has high exposure to vehicular pollution. As per Larsen et al. (2007), transport-related pollution and bark acidity can influence lichen distribution in some areas.

Among cultivated ecosystems, arecanut and coconut plantations had a greater number of lichens than tea and coffee plantations. Macrolichens such as Dirinaria consimilis, Hypotrachyna infirma, Parmotrema cristiferum, P. praesorediosum, P. tinctorum, and Physcia tribacoides were found distributed in the arecanut plantations. Coconut plantations support species like Dirinaria consimilis, Parmotrema tinctorum, $P$. praesorediosum, Physcia dilatate, and $P$. tribacoides. However, tea plantations in the study area inhabit only three species, Dirinaria consimilis, Physcia dilatata, and $P$. tribacoides; and coffee plantations supports only Physcia dilatata and P. tribacoides. Since, trees are considered as the major supporting system for the successful growth of lichens in tropical vegetations, the bark character, aspects and height of the tree are of greater importance in the distribution of lichens (John 1992). Nayaka et al. (2006) enumerated the occurrence of 23 lichen species on coconut and arecanut orchard of Goa in which crustose lichens were dominated with 17 species, while foliose and fruticose lichens exhibit scarce growth.

With regard to the altitudinal variation, distribution and occurrence of lichens were highest from 840-860 m. The variation of species occurrence along the different 
Table 2. Check list of lichens collected from the study area.

\begin{tabular}{|c|c|c|c|c|c|}
\hline & Name & Family & Growth form & Substratum & Localities \\
\hline 1. & $\begin{array}{l}\text { Coccocarpia palmicola (Spreng.) Arvidss. } \\
\text { \& D.J. Galloway }\end{array}$ & Coccocarpiaceae & Foliose & Corticolous & $\begin{array}{l}\text { Munderi, Emily, Turkey, } \\
\text { Ambilery, Vellaramkunnu } \\
\text { Onivayal, Gramathuvayal }\end{array}$ \\
\hline 2. & Dirinaria consimilis (Stirton) D.D. Awasthi & Caliciaceae & Foliose & Corticolous & Maravayal, Adlayed, Pallythazhe \\
\hline 3. & $\begin{array}{l}\text { Heterodermia comosa (Eschw.) Follmann } \\
\text { \& Redon }\end{array}$ & Physciaceae & Foliose & Corticolous & $\begin{array}{l}\text { Maniangode, Emily, Puthiya Bus Stand, } \\
\text { Municipal Office, Rattakolly, Vellaramkunnu }\end{array}$ \\
\hline 4. & $\begin{array}{l}\text { Heterodermia galactophylla (Tuck.) W.L. } \\
\text { Culb. }\end{array}$ & Physciaceae & Foliose & Corticolous & $\begin{array}{l}\text { Civil Station, Onivayal, Chathothuvayal, } \\
\text { Nedungode } \\
\text { Adlayed, Govt.High School }\end{array}$ \\
\hline 5. & $\begin{array}{l}\text { Heterodermia hypocaesia (Yasuda ex } \\
\text { Rasanen) D.D. Awasthi }\end{array}$ & Physciaceae & Foliose & Corticolous & $\begin{array}{l}\text { Civil Station, Kainatty, Rattakolly } \\
\text { Perumthatta, Turkey, Edaguni } \\
\text { Onivayal }\end{array}$ \\
\hline 6. & $\begin{array}{l}\text { Heterodermia hypochraea (Vain.) } \\
\text { Swinsc. \& Krog }\end{array}$ & Physciaceae & Foliose & Corticolous & Civil Station \\
\hline 7. & $\begin{array}{l}\text { Heterodermia japonica (M.Sato) Swinsc. } \\
\& \text { Krog }\end{array}$ & Physciaceae & Foliose & Corticolous & $\begin{array}{l}\text { Maravayal, Nedungode, Perumthatta, Govt. } \\
\text { High School, Puthoorvayal, Madiyoorkuni } \\
\text { Edaguni }\end{array}$ \\
\hline 8. & Heterodermia obscurata (Nyl.) Trevis. & Physciaceae & Foliose & Corticolous & $\begin{array}{l}\text { Civil Station, Nedungode, } \\
\text { Puthoorvayal,Madiyoorkuni, } \\
\text { Emily }\end{array}$ \\
\hline 9. & Heterodermia speciosa (Wulf.) Trevis. & Physciaceae & Foliose & Corticolous & $\begin{array}{l}\text { Civil Station,Onivayal,Govt.High } \\
\text { School,Edaguni,Maniangode, } \\
\text { Adlayed }\end{array}$ \\
\hline 10. & Hypotrachyna infirma (Kurok.) Hale & Parmeliaceae & Foliose & Corticolous & $\begin{array}{l}\text { Civil station, Edaguni, Madiyoorkuni,Ambilery } \\
\text { Pallythazhe,Kainatty }\end{array}$ \\
\hline 11. & Leptogium denticulatum Nyl. & Collemataceae & Foliose & Saxicolous & $\begin{array}{l}\text { Civil Station, Puliyarmala, Ambilery, Pulpara, } \\
\text { Rattakolly } \\
\text { Vellaramkunnu }\end{array}$ \\
\hline 12. & Leptogium sp. & Collemataceae & Foliose & Saxicolous & $\begin{array}{l}\text { Civil Station, Onivayal, } \\
\text { Kanyagurukulam,Adlayed, Perumthatta }\end{array}$ \\
\hline 13. & Myelochroa perisidians (Nyl.) Elix \& Hale & Parmeliaceae & Foliose & Saxicolous & $\begin{array}{l}\text { Munderi, Turkey, Kanyagurukulam, } \\
\text { Puthoorvayal Quarry }\end{array}$ \\
\hline 14. & Parmotrema cristiferum (Taylor) Hale & Parmeliaceae & Foliose & Corticolous & $\begin{array}{l}\text { Emily, Pulpara,Turkey, Puliyarmala, Perumthatta } \\
\text { Puthoorvayal Quarry }\end{array}$ \\
\hline 15. & Parmotrema praesorediosum (Nyl.) Hale & Parmeliaceae & Foliose & Corticolous & $\begin{array}{l}\text { Civil Station, Pulpara, Puthoorvayal,Emily, } \\
\text { Thadam, } \\
\text { Kanyagurukulam }\end{array}$ \\
\hline 16. & $\begin{array}{l}\text { Parmotrema tinctorum (Despr. ex Nyl.) } \\
\text { Hale }\end{array}$ & Parmeliaceae & Foliose & Corticolous & $\begin{array}{l}\text { Rattakolly,Kainatty,Gramathuvayal,Turkey,Puth } \\
\text { iya Bus Stand } \\
\text { Municipal Office, Munderi }\end{array}$ \\
\hline 17. & Phaeophyscia ciliata (Hoffm.) Moberg & Physciaceae & Foliose & Saxicolous & $\begin{array}{l}\text { Civil Station, Adlayed,Maniangode,Edaguni } \\
\text { Perumthatta,Kainatty, Chathothuvayal }\end{array}$ \\
\hline 18. & Physcia dilatata Nyl. & Physciaceae & Foliose & Corticolous & $\begin{array}{l}\text { Maravayal, Emily, Puthiya Bus Stand, } \\
\text { Maravayal, Puliyarmala }\end{array}$ \\
\hline 19. & Physcia tribacoides Nyl. & Physciaceae & Foliose & Corticolous & $\begin{array}{l}\text { Puthoorvayal Quarry, Emily, Thadam, } \\
\text { Maravayal }\end{array}$ \\
\hline 20. & Pseudocyphellaria aurata (Ach.) Vain. & Lobariaceae & Foliose & Corticolous & $\begin{array}{l}\text { Civil Station, Edaguni, Chathothuvayal,Munderi } \\
\text { Gramathuvayal,Municipal Office } \\
\text { Maravayal,Puliyarmala }\end{array}$ \\
\hline 21. & Ramalina sp. & Ramalinaceae & Fruticose & Corticolous & Munderi \\
\hline
\end{tabular}

altitudinal gradients shows that the distribution and occurrence of lichens vary with altitude. Negi \& Upreti (2000) observed that species richness of lichens was low at lower altitude gradually rises to a peak at middle altitudes and then fall significantly at higher altitudes while working along the altitudinal gradients in the rock microhabitat of Hemis National Park, in Ladakh. Mishra \& Upreti (2015) also observed that diversity of lichens changed with altitude in Govind Wildlife
Sanctuary, Uttarakhand. The most probable reason for poor diversity in different localities situated in lower altitudes may be due to environmental conditions, heavy anthropogenic pressure as the inhabitants of the villages largely depend for their fuel and fodder needs on the nearby forest area which resulted into destruction of forests. 


\section{REFERENCES}

Awasthi, D.D. (1991). A Key to the Microlichens of India, Nepal and Sri Lanka. Bibliotheca Lichenologica 40: 1-337.

Awasthi, D.D. (2007). Compendium of the Macrolichens from India, Nepal and Sri Lanka. Bishen Singh Mahendra Pal Singh, Dehradun, India, $580 \mathrm{pp}$.

Bhat, S., S.N. Dudani., M.D.S. Chandran \& T.V. Ramachandra (2011). Lichens of Western Ghats. http://wgbis.ces.iisc.ernet. in/biodiversity/sahyadri_enews/newsletter/issue34/lichens westernghats/index.htm

Biju, H., R.G. Bagool \& S. Nayaka (2010). Additions to the lichen flora of Kerala State I: Parmelioid macro-lichens. Journal of Economic and Taxonomic Botany 34(4): 890-897.

Biju, H., R. Bagool, S.Nayaka \& T. Palode (2012). Additions to the Lichen Flora of Kerala State II: Graphidaceae. Journal of Economic and Taxonomic Botany 36(4): 867-873.

Divakar, P.K. \& D.K. Upreti (2005). Parmelioid Lichens in India (A Revisionary study). Bishen Singh Mahendra Pal Singh, Dehradun.

Easa, P.S. (2003). Biodiversity documentation of Kerala Part 3: Lichens. Kerala Forest Research Institute, Peechi, Kerala, 61 pp.

Fryday, A.M. (2000). The lichen vegetation associated with areas of late snow lie in the Scottish highlands. Lichenologist 33: 121-150.

John, E.A. (1992). Distribution patterns and inter thalline interactions of epiphytic foliose lichens. Canadian Journal of Botany 70: 818823.

Kumar, M \& S. Sequiera (2003). Notes on a collection of some lichens from Chembra and Thirunelly hills of Wayanad Districts, Kerala State, India. Journal of Economic and Taxonomic Botany 27(Suppl.): 1029-1039.

Kumar, M.S.M. (2000). Lichen (Macrolichen) Flora of Kerala Part of Western Ghats, KFRI Research Report 194, Kerala Forest Research Institute, Peechi, Kerala, 186 pp.

Larsen, R.S., J.N. B. Bell., P.W. James., P.J. Chimonides., F.J. Rumsey, A. Tremper \& O.W. Purvis (2007). Lichen and bryophyte distribution on oak in London in relation to air pollution and bark acidity. Environmental pollution 146(2): 332-340.

Mesta, A.R. \& V.S. Kanivebagilu (2015). Distribution Pattern and Ecology of Usneoid lichens in Western Ghats, Southern India. Journal on New Biological Reports 4: 247-254.

Mishra, G.K. \& D.K. Upreti (2015). Altitudinal distribution of cetrarioid lichens in Govind Wildlife Sanctuary, Garhwal Himalaya, Uttarakhand, India. Geophytology 45(1): 9-19.

Nayaka, S., D.K. Upreti, S. Phatak \& C. Samuel (2006). Preliminary observation on lichen flora of coconut and arecanut orchards of Goa, India. Phytotaxonomy 6: 23-25.

Nayaka, S. \& D.K. Upreti (2011). Lichens diversity in Western Ghats: Need for quantitative assessment and conservation. Report of the Western Ghats Ecology Expert Panel. Ministry of Environment and Forests, Government of India, https://www.researchgate.net/ publication/266143899

Nayaka, S. (2014). Methods and techniques in collection, preservation and identification of lichens, pp. 101-128. In: Rana, T.S., K.N. Nair \& D.K. Upreti (eds.). Plant Taxonomy and Biosystematics-Classical and Modern Methods. New India Publishing Agency, New Delhi.

Negi, H.R. \& D.K. Upreti 2000. Species diversity and relative abundance of lichens in Rumbak catchment of Hemis National Park in Ladhak. Current Science 78: 1105-1112.

Orange, A., P.W. James \& F.J. White (2001). Microchemical methods for the identification of Lichens. British Lichen Society, Natural History Museum, London, UK.
Patwardhan, P.G. (1983). Rare and endemic lichens of Western Ghats, South Western India, pp. 318-322. In: Jain, S.K. \& R.R. Rao (eds.). An assessment of threatened plants of India. Botanical Survey of India, Howrah.

Singh, K.P. \& G.P. Sinha (2010). Indian lichens: an annotated checklist. Botanical Survey of India. Shiva Offset Press, Dehradun, Uttarakhand.

Sinha, G.P., S. Nayaka \& S. Joseph (2018). Additions to the checklist of Indian lichens after 2010. Cryptogam Biodiversity and Assessment Special Volume (2018): 197-206. https://doi.org/10.21756/cab. esp16.

Sequiera, S. (2003). Taxonomy and Ecology of lichens of Silent Valley National Park, Southern Western Ghats, India. PhD Thesis, FRI, Dehradun.

Sequiera, S. (2007). Lichens of high ranges and their utilization potential. Technical report, KSCSTE, Thiruvananthapuram, $78 \mathrm{pp}$.

Sreekumar, V.B., K.H. Hussain \& C. Renuka (2017). Virtual herbarium of Kerala Forest Research Institute, Peechi, Kerala, India. Current Science 112: 466-470.

Zachariah, S.A., S. Nayaka, S. Joseph, P. Gupta, S. Thomas \& S.K. Varghese (2018). New and noteworthy records of lichens from Pathanamthitta district, Kerala. Studies in Fungi 3(1): 349-356. https://doi.org/10.5943/sif/3/1/35

Zachariah, S.A., S. Nayaka, P. Gupta \& S.K. Varghese (2019). The lichen genus Pyxine (Caliciaceae) in Kerala state with $P$. dactyloschmidtii as new to India. Hattoria 10: 109-117.

Zachariah, S.A., S. Nayaka, S. Joseph, P. Gupta \& S. K. Varghese (2020). Eleven new records of lichens to the state of Kerala, India. Journal of Threatened Taxa 12(10): 16402-16406. https://doi.org/10.11609/ jott.5475.12.10.16402-16406

Wijayawardene, N.N., K.D. Hyde, L.K.T. Al-Ani, L. Tedersoo, D. Haelewaters, K.C. Rajeshkumar, R.L. Zhao, A. Aptroot, D. Leontyev, R.K. Saxena, Y.S. Tokarev, D.Q. Dai, P.M. Letcher, S.L. Stephenson, D. Ertz, H.T. Lumbsch, M. Kukwa, I.V. Issi, H. Madrid, A.J.L. Phillips, L. Selbmann, W.P. Pfliegler, E. Horváth, K. Bensch, P.M. Kirk, K. Kolaříková, H.A. Raja, R. Radek, V. Papp, V. Dima, J. Ma, E. Malosso, S. Takamatsu, G. Rambold, P.B. Gannibal, D. Triebel, A.K. Gautam, S. Avasthi, S. Suetrong, E. Timdal, S.C. Fryar, G. Delgado, M. Réblová, M. Doilom, S. Dolatabadi, J. Pawłowska, R. Humber, R. Kodsueb, I. Sánchez-Castro, B.T. Goto, D.K.A. Silva, F.A. de Souza, F.Oehl, G.A. da Silva, I.R. Silva, J. Błaszkowski, K. Jobim, L. Maia, F. Barbosa, P. Fiuza, P. Divakar, B. Shenoy, R.F. Castañeda-Ruiz, S. Somrithipol, A.A. Lateef, S.C. Karunarathna, S. Tibpromma, P.E. Mortimer, D.N. Wanasinghe, R. Phookamsak, J. Xu, Y. Wang, F. Tian, P. Alvarado, D.W. Li, I. Kušan, N. Matočec, A. Mešić, Z. Tkalčec, S. Maharachchikumbura, M. Papizadeh, G. Heredia, F. Wartchow, M. Bakhshi, E. Boehm, N. Youssef, V. Hustad, J. Lawrey, A. Santiago, J. Bezerra, C. Souza-Motta, A. Firmino, Q. Tian, J. Houbraken, S. Hongsanan, K. Tanaka, A. Dissanayake, J. Monteiro, H. Grossart, A. Suija, G. Weerakoon, J. Etayo, A. Tsurykau, V. Vázquez, P. Mungai, U. Damm, Q.R. Li, H. Zhang, S. Boonmee, Y.Z. Lu, A.G. Becerra, B. Kendrick, F.Q. Brearley, J. Motiejūnaitè, B. Sharma, R. Khare, S. Gaikwad, D. Wijesundara, L. Tang, M. He, A. Flakus, P. RodriguezFlakus, M. Zhurbenko, E. McKenzie, M. Stadler, D. Bhat, J. Liu, M. Raza, R. Jeewon, E. Nassonova, M. Prieto, R. Jayalal, M. Erdoğdu, A. Yurkov, M. Schnittler, O. Shchepin, Y. Novozhilov, A. Silva-Filho, E. Gentekaki, P. Liu, J. Cavender, Y. Kang, S. Mohammad, L. Zhang, R. Xu, Y. Li, M. Dayarathne, A. Ekanayaka, T. Wen, C. Deng, O. Pereira, S. Navathe, D. Hawksworth, X. Fan, L. Dissanayake, E. Kuhnert, H. Grossart \& M. Thines (2020). Outline of Fungi and fungus-like taxa. Mycosphere 11(1): 1060-1456. https://doi.org/10.5943/ mycosphere/11/1/8 

Dr. John Noyes, Natural History Museum, London, UK

Dr. Albert G. Orr, Griffith University, Nathan, Australia

Dr. Sameer Padhye, Katholieke Universiteit Leuven, Belgium

Dr. Nancy van der Poorten, Toronto, Canada

Dr. Kareen Schnabel, NIWA, Wellington, New Zealand

Dr. R.M. Sharma, (Retd.) Scientist, Zoological Survey of India, Pune, India

Dr. Manju Siliwal, WILD, Coimbatore, Tamil Nadu, India

Dr. G.P. Sinha, Botanical Survey of India, Allahabad, India

Dr. K.A. Subramanian, Zoological Survey of India, New Alipore, Kolkata, India

Dr. P.M. Sureshan, Zoological Survey of India, Kozhikode, Kerala, India

Dr. R. Varatharajan, Manipur University, Imphal, Manipur, India

Dr. Eduard Vives, Museu de Ciències Naturals de Barcelona, Terrassa, Spain

Dr. James Young, Hong Kong Lepidopterists' Society, Hong Kong

Dr. R. Sundararaj, Institute of Wood Science \& Technology, Bengaluru, India

Dr. M. Nithyanandan, Environmental Department, La Ala Al Kuwait Real Estate. Co. K.S.C.,

Kuwait

Dr. Himender Bharti, Punjabi University, Punjab, India

Mr. Purnendu Roy, London, UK

Dr. Saito Motoki, The Butterfly Society of Japan, Tokyo, Japan

Dr. Sanjay Sondhi, TITLI TRUST, Kalpavriksh, Dehradun, India

Dr. Nguyen Thi Phuong Lien, Vietnam Academy of Science and Technology, Hanoi, Vietnam

Dr. Nitin Kulkarni, Tropical Research Institute, Jabalpur, India

Dr. Robin Wen Jiang Ngiam, National Parks Board, Singapore

Dr. Lional Monod, Natural History Museum of Geneva, Genève, Switzerland.

Dr. Asheesh Shivam, Nehru Gram Bharti University, Allahabad, India

Dr. Rosana Moreira da Rocha, Universidade Federal do Paraná, Curitiba, Brasi

Dr. Kurt R. Arnold, North Dakota State University, Saxony, Germany

Dr. James M. Carpenter, American Museum of Natural History, New York, USA

Dr. David M. Claborn, Missouri State University, Springfield, USA

Dr. Kareen Schnabel, Marine Biologist, Wellington, New Zealand

Dr. Amazonas Chagas Júnior, Universidade Federal de Mato Grosso, Cuiabá, Brasil

Mr. Monsoon Jyoti Gogoi, Assam University, Silchar, Assam, India

Dr. Heo Chong Chin, Universiti Teknologi MARA (UiTM), Selangor, Malaysia

Dr. R.J. Shiel, University of Adelaide, SA 5005, Australia

Dr. Siddharth Kulkarni, The George Washington University, Washington, USA

Dr. Priyadarsanan Dharma Rajan, ATREE, Bengaluru, India

Dr. Phil Alderslade, CSIRO Marine And Atmospheric Research, Hobart, Australia

Dr. John E.N. Veron, Coral Reef Research, Townsville, Australia

Dr. Daniel Whitmore, State Museum of Natural History Stuttgart, Rosenstein, Germany.

Dr. Yu-Feng Hsu, National Taiwan Normal University, Taipei City, Taiwan

Dr. Keith V. Wolfe, Antioch, California, USA

Dr. Siddharth Kulkarni, The Hormiga Lab, The George Washington University, Washington,

D.C., USA

Dr. Tomas Ditrich, Faculty of Education, University of South Bohemia in Ceske

Budejovice, Czech Republic

Dr. Mihaly Foldvari, Natural History Museum, University of Oslo, Norway

Dr. V.P. Uniyal, Wildlife Institute of India, Dehradun, Uttarakhand 248001, India

Dr. John T.D. Caleb, Zoological Survey of India, Kolkata, West Bengal, India

Dr. Priyadarsanan Dharma Rajan, Ashoka Trust for Research in Ecology and the Environment

(ATREE), Royal Enclave, Bangalore, Karnataka, India

\section{Fishes}

Dr. Neelesh Dahanukar, IISER, Pune, Maharashtra, India

Dr. Topiltzin Contreras MacBeath, Universidad Autónoma del estado de Morelos, México

Dr. Heok Hee Ng, National University of Singapore, Science Drive, Singapore

Dr. Rajeev Raghavan, St. Albert's College, Kochi, Kerala, India

Dr. Robert D. Sluka, Chiltern Gateway Project, A Rocha UK, Southall, Middlesex, UK

Dr. E. Vivekanandan, Central Marine Fisheries Research Institute, Chennai, India

Dr. Davor Zanella, University of Zagreb, Zagreb, Croatia

Dr. A. Biju Kumar, University of Kerala, Thiruvananthapuram, Kerala, India

Dr. Akhilesh K.V., ICAR-Central Marine Fisheries Research Institute, Mumbai Research

Centre, Mumbai, Maharashtra, India

Dr. J.A. Johnson, Wildlife Institute of India, Dehradun, Uttarakhand, India

Amphibians

Dr. Sushil K. Dutta, Indian Institute of Science, Bengaluru, Karnataka, India

Dr. Annemarie Ohler, Muséum national d'Histoire naturelle, Paris, France

\section{Reptiles}

Dr. Gernot Vogel, Heidelberg, Germany

Dr. Raju Vyas, Vadodara, Gujarat, India

Dr. Pritpal S. Soorae, Environment Agency, Abu Dubai, UAE.

Prof. Dr. Wayne J. Fuller, Near East University, Mersin, Turkey

Prof. Chandrashekher U. Rivonker, Goa University, Taleigao Plateau, Goa. India

Dr. S.R. Ganesh, Chennai Snake Park, Chennai, Tamil Nadu, India

Dr. Himansu Sekhar Das, Terrestrial \& Marine Biodiversity, Abu Dhabi, UAE
Birds

Dr. Hem Sagar Baral, Charles Sturt University, NSW Australia

Dr. Chris Bowden, Royal Society for the Protection of Birds, Sandy, UK

Dr. Priya Davidar, Pondicherry University, Kalapet, Puducherry, India

Dr. J.W. Duckworth, IUCN SSC, Bath, UK

Dr. Rajah Jayapal, SACON, Coimbatore, Tamil Nadu, India

Dr. Rajiv S. Kalsi, M.L.N. College, Yamuna Nagar, Haryana, India

Dr. V. Santharam, Rishi Valley Education Centre, Chittoor Dt., Andhra Pradesh, India

Dr. S. Balachandran, Bombay Natural History Society, Mumbai, India

Mr. J. Praveen, Bengaluru, India

Dr. C. Srinivasulu, Osmania University, Hyderabad, India

Dr. K.S. Gopi Sundar, International Crane Foundation, Baraboo, USA

Dr. Gombobaatar Sundev, Professor of Ornithology, Ulaanbaatar, Mongolia

Prof. Reuven Yosef, International Birding \& Research Centre, Eilat, Israel

Dr. Taej Mundkur, Wetlands International, Wageningen, The Netherlands

Dr. Carol Inskipp, Bishop Auckland Co., Durham, UK

Dr. Tim Inskipp, Bishop Auckland Co, Durham, UK

Dr. V. Gokula, National College, Tiruchirappalli, Tamil Nadu, India

Dr. Arkady Lelej, Russian Academy of Sciences, Vladivostok, Russia

Dr. Simon Dowell, Science Director, Chester Zoo, UK

Dr. Mário Gabriel Santiago dos Santos, Universidade de Trás-os-Montes e Alto Douro,

Quinta de Prados, Vila Real, Portugal

Dr. Grant Connette, Smithsonian Institution, Royal, VA, USA

Dr. M. Zafar-ul Islam, Prince Saud Al Faisal Wildlife Research Center, Taif, Saudi Arabia

Mammals

Dr. Giovanni Amori, CNR - Institute of Ecosystem Studies, Rome, Italy

Dr. Anwaruddin Chowdhury, Guwahati, India

Dr. David Mallon, Zoological Society of London, UK

Dr. Shomita Mukherjee, SACON, Coimbatore, Tamil Nadu, India

Dr. Angie Appel, Wild Cat Network, Germany

Dr. P.O. Nameer, Kerala Agricultural University, Thrissur, Kerala, India

Dr. Ian Redmond, UNEP Convention on Migratory Species, Lansdown, UK

Dr. Heidi S. Riddle, Riddle's Elephant and Wildlife Sanctuary, Arkansas, USA

Dr. Karin Schwartz, George Mason University, Fairfax, Virginia.

Dr. Lala A.K. Singh, Bhubaneswar, Orissa, India

Dr. Mewa Singh, Mysore University, Mysore, India

Dr. Paul Racey, University of Exeter, Devon, UK

Dr. Honnavalli N. Kumara, SACON, Anaikatty P.O., Coimbatore, Tamil Nadu, India

Dr. Nishith Dharaiya, HNG University, Patan, Gujarat, India

Dr. Spartaco Gippoliti, Socio Onorario Società Italiana per la Storia della Fauna "Giuseppe

Altobello", Rome, Italy

Dr. Justus Joshua, Green Future Foundation, Tiruchirapalli, Tamil Nadu, India

Dr. H. Raghuram, The American College, Madurai, Tamil Nadu, India

Dr. Paul Bates, Harison Institute, Kent, UK

Dr. Jim Sanderson, Small Wild Cat Conservation Foundation, Hartford, USA

Dr. Dan Challender, University of Kent, Canterbury, UK

Dr. David Mallon, Manchester Metropolitan University, Derbyshire, UK

Dr. Brian L. Cypher, California State University-Stanislaus, Bakersfield, CA

Dr. S.S. Talmale, Zoological Survey of India, Pune, Maharashtra, India

Prof. Karan Bahadur Shah, Budhanilakantha Municipality, Kathmandu, Nepal

Dr. Susan Cheyne, Borneo Nature Foundation International, Palangkaraja, Indonesia

Dr. Hemanta Kafley, Wildlife Sciences, Tarleton State University, Texas, USA

\section{Other Disciplines}

Dr. Aniruddha Belsare, Columbia MO 65203, USA (Veterinary)

Dr. Mandar S. Paingankar, University of Pune, Pune, Maharashtra, India (Molecular)

Dr. Jack Tordoff, Critical Ecosystem Partnership Fund, Arlington, USA (Communities)

Dr. Ulrike Streicher, University of Oregon, Eugene, USA (Veterinary)

Dr. Hari Balasubramanian, EcoAdvisors, Nova Scotia, Canada (Communities)

Dr. Rayanna Hellem Santos Bezerra, Universidade Federal de Sergipe, São Cristóvão, Brazil

Dr. Jamie R. Wood, Landcare Research, Canterbury, New Zealand

Dr. Wendy Collinson-Jonker, Endangered Wildlife Trust, Gauteng, South Africa

Dr. Rajeshkumar G. Jani, Anand Agricultural University, Anand, Gujarat, India

Dr. O.N. Tiwari, Senior Scientist, ICAR-Indian Agricultural Research Institute (IARI), New

Delhi, India

Dr. L.D. Singla, Guru Angad Dev Veterinary and Animal Sciences University, Ludhiana, India

Dr. Rupika S. Rajakaruna, University of Peradeniya, Peradeniya, Sri Lanka

Dr. Bahar Baviskar, Wild-CER, Nagpur, Maharashtra 440013, India

Reviewers 2018-2020

Due to pausity of space, the list of reviewers for $2018-2020$ is available online.

The opinions expressed by the authors do not reflect the views of the Journal of Threatened Taxa, Wildlife Information Liaison Development Society, Zoo Outreach Organization, or any of the partners. The journal, the publisher, the host, and the partners are not responsible for the accuracy of the political boundaries shown in the maps by the authors.

Journal of Threatened Taxa is indexed/abstracted in Bibliography of Systematic Mycology, Biological Abstracts, BIOSIS Previews, CAB Abstracts, EBSCO, Google Scholar, Index Copernicus, Index Fungorum, JournalSeek, National Academy of Agricultural Sciences, NewJour, OCLC WorldCat, SCOPUS, Stanford University Libraries, Virtual Library of Biology, Zoological Records.

NAAS rating (India) 5.64
Print copies of the Journal are available at cost. Write to:

The Managing Editor, JoTT,

c/o Wildlife Information Liaison Development Society,

No. 12, Thiruvannamalai Nagar, Saravanampatti - Kalapatti Road,

Saravanampatti, Coimbatore, Tamil Nadu 641035, India

ravi@threatenedtaxa.org 


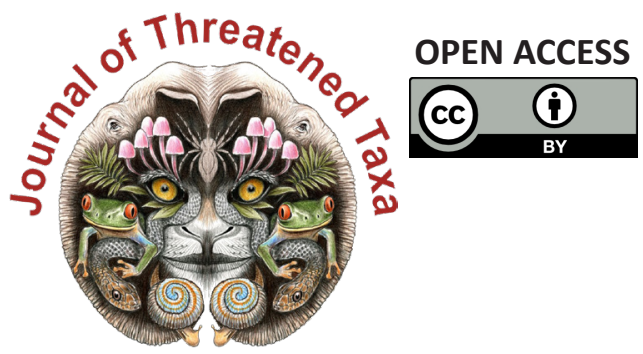

www.threatenedtaxa.org

The Journal of Threatened Taxa (JoTT) is dedicated to building evidence for conservation globally by publishing peer-reviewed articles online every month at a reasonably rapid rate at www.threatenedtaxa.org. All articles published in JoTT are registered under Creative Commons Attribution 4.0 International License unless otherwise mentioned. JoTT allows allows unrestricted use, reproduction, and distribution of articles in any medium by providing adequate credit to the author(s) and the source of publication.

\section{ISSN $0974-7907$ (Online) | ISSN $0974-7893$ (Print)}

\section{December 2021 | Vol. 13 | No. 14 | Pages: 20143-20310 \\ Date of Publication: 26 December 2021 (Online \& Print) DOI: 10.11609/jott.2021.13.14.20143-20310}

\section{Communications}

Updated distribution of seven Trichosanthes L. (Cucurbitales: Cucurbitaceae) taxa in India, along with taxonomic notes

Kanakasabapathi Pradheep, Soyimchiten, Ganjalagatta Dasaiah Harish, Muhammed Abdul Nizar, Kailash Chandra Bhatt, Anjula Pandey \& Sudhir Pal Ahlawat, Pp. 20143-20152

Dragonflies and Damselflies (Insecta: Odonata) of Aryanad Grama Panchayat, Kerala, India

- Reji Chandran \& A. Vivek Chandran, Pp. 20153-20166

Checklist of Odonata (Insecta) of Doon Valley, Uttarakhand, India

- Kritish De, Sarika Bhatt, Amar Paul Singh, Manisha Uniyal \& Virendra Prasad Uniyal, Pp. 20167-20173

Diversity of moths from the urban set-up of Valmiki Nagar, Chennai, India - Vikas Madhav Nagarajan, Rohith Srinivasan \& Mahathi Narayanaswamy, Pp. 20174-20189

Ichthyofaunal diversity with relation to environmental variables in the snowfed Tamor River of eastern Nepal

- Jawan Tumbahangfe, Jash Hang Limbu, Archana Prasad, Bhrarat Raj Subba \& Dil Kumar Limbu, Pp. 20190-20200

Observations on the foraging behavior of Tricoloured Munia Lonchura malacca (Linnaeus, 1766) and its interaction with pearl millet fields in Villupuram District, Tamil Nadu, India

- M. Pandian, Pp. 20201-20208

Roosting patterns of House Sparrow Passer domesticus Linn., 1758 (Aves: Passeridae) in Bhavnagar, Gujarat, India

- Foram P. Patel \& Pravinsang P. Dodia, Pp. 20209-20217

Review

Comprehensive checklist of algal class Chlorophyceae (sensu Fritsch, 1935) for Uttar Pradesh, India, with updated taxonomic status

- Sushma Verma, Kiran Toppo \& Sanjeeva Nayaka, Pp. 20218-20248

\section{View Point}

Wildlife managers ignore previous knowledge at great risk: the case of Rivaldo, the iconic wild Asian Elephant Elephas maximus L. of the Sigur Region, Nilgiri Biosphere Reserve, India

- Jean-Philippe Puyravaud \& Priya Davidar, Pp. 20249-20252

\section{Short Communications}

Diversity and distribution of macro lichens from Kalpetta Municipality of Wayanad District, Kerala, India

- Greeshma Balu, A.R. Rasmi, Stephen Sequeira \& Biju Haridas, Pp. 20253-20257

Extended distribution of two endemic epiphytes from the Western Ghats to the Deccan Plateau

- Sonali Vishnu Deore, Mangala Dala Sonawane \& Sharad Suresh Kambale, Pp. 20258-20260

Nomenclatural notes and report of Boehmeria penduliflora Wedd. ex D.G. Long from the Terai region of Uttar Pradesh, India

- Amit Gupta, Imtiyaz Ahmad Hurrah, Aparna Shukla \& Vijay V. Wagh, Pp. 2026120265
New distribution record of a true coral species, Psammocora contigua (Esper, 1794) from Gulf of Kachchh Marine National Park \& Sanctuary, India - R. Chandran, R. Senthil Kumaran, D.T. Vasavada, N.N. Joshi \& Osman G. Husen, Pp. 20266-20271

A new species of flat-headed mayfly Afronurus meenmutti (Ephemeroptera: Heptageniidae: Ecdyonurinae) from Kerala, India

- Marimuthu Muthukatturaja \& Chellaiah Balasubramanian, Pp. 20272-20277

Photographic record of Dholes predating on a young Banteng in southwestern Java, Indonesia

- Dede Aulia Rahman, Mochamad Syamsudin, Asep Yayus Firdaus, Herry Trisna Afriandi \& Anggodo, Pp. 20278-20283

Latrine site and its use pattern by Large Indian Civet Viverra zibetha Linnaeus, 1758: record from camera trap

- Bhuwan Singh Bist, Prashant Ghimire, Basant Sharma, Chiranjeevi Khanal \& Anoj Subedi, Pp. 20284-20287

Notes

Two additions to the flora of Kerala, India

- P. Murugan, Basil Paul \& M. Sulaiman, Pp. 20288-20291

Pentatropis R.Br. ex Wight \& Arn. (Apocynaceae), a new generic record for Kerala, India

- V. Ambika, Jose Sojan \& V. Suresh, Pp. 20292-20294

New record of Kashmir Birch Mouse Sicista concolor leathemi (Thomas, 1893) (Rodentia: Sminthidae) in the Indian Himalaya

- S.S. Talmale, Avtar Kaur Sidhu \& Uttam Saikia, Pp. 20295-20298

Breeding record of Black-headed Ibis Threskiornis melanocephalus (Aves: Threskiornithidae) at Mavoor wetland, Kozhikode District, Kerala, India - C.T. Shifa, Pp. 20299-20301

\section{Response}

Crop and property damage caused by Purple-faced Langurs Trachypithecus vetulus (Mammalia: Primates: Cercopithecidae) - Vincent Nijman, Pp. 20302-20306

Reply

If habitat heterogeneity is effective for conservation of butterflies in urban landscapes of Delhi, India? Unethical publication based on data manipulation: Response of original authors

- Monalisa Paul \& Aisha Sultana, Pp. 20307-20308

\section{Book Review}

Freshwater fishes of the Arabian Peninsula - Rajeev Raghavan, Pp. 20309-20310

Publisher \& Host

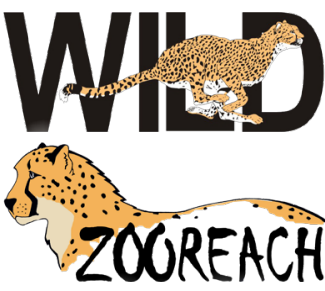

Threatened Taxa 